\title{
PENGARUH KUALITAS PRODUK, HARGA, PROMOSI DAN ATRIBUT PRODUK TERHADAP KEPUTUSAN PEMBELIAN PASTA GIGI PEPSODENT PADA MAHASISWA JURUSAN EKONOMI SYARIAH FAKULTAS EKONOMI DAN BISNIS ISLAM IAIN PADANGSIDIMPUAN
}

\author{
Budi Gautama Siregar, Hamni Fadlilah Nasution, Siti Aisyah \\ IAIN Padangsidimpuan \\ Jalan T. Rizal Nurdin Km. 4,5 Sihitang, Padangsidimpuan \\ Email : zulaikamatondang83@gmail.com
}

\begin{abstract}
Abstrak,
Penelitian ini dilakukan dengan tujuan untuk mengetahui pengaruh kualitas produk, harga, promosi dan atribut produk terhadap keputusan pembelian pasta gigi pepsodent pada mahasiswa jurusan ekonomi syariah fakultas ekonomi dan bisnis islam IAIN padangsidimpuan. Penelitian ini merupakan penelitian kuantitatif. Sampel yang digunakan dalam penelitian ini sebanyak 92 orang. Teknik pengumpulan data yang digunakan adalah teknik angket dan observasi untuk kelengkapan data pada penelitian ini. Analisis dengan menggunakan statistik yaitu SPSS versi 22. Hasil analisis koefesien determinasi (R) dapat diketahui bahwa nilai $\mathrm{r}=0,727$ artinya korelasi antara variabel kualitas produk, harga, promosi dan atribut produk terhadap keputusan pembelian terjadi hubungan yang kuat. Nilai Adjusted $\mathrm{R}^{2}$ sebesar 0,507 atau 50,7 \% menunjukkan variabel kualitas produk, harga, promosi dan atribut produk mempengaruhi keputusan pembelian dan sisanya 49,3\% dipengaruhi oleh faktor-faktor lain diluar penelitian yang dilakukan oleh peneliti. Berdasarkan hasil penelitian ini ada pengaruh kualitas produk terhadap keputusan pembelian pasta gigi pepsodent dengan nilai $t_{\text {hitung }}>t_{\text {tabel }}(5,111>1,663)$. Variabel harga ada pengaruh terhadap keputusan pembelian pasta gigi pepsodent dengan nilai $(1,670>1,663)$. Variabel promosi ada pengaruh terhadap keputusan pembelian pasta gigi pepsodent dengan nilai $(1,755>1,663)$. Variabel atribut produk ada pengaruh terhadap keputusan pembelian pasta gigi pepsodent dengan nilai $(4,552>1,663)$. Dapat disimpulkan bahwa ada pengaruh yang signifikan antara variabel kualitas produk, harga, promosi dan atribut produk terhadap keputusan pembelian pasta gigi pepsodent pada Mahasiswa Jurusan Ekonomi Syariah Fakultas Ekonomi dan Bisnis Islam IAIN Padangsidimpuan.
\end{abstract}

Kata Kunci: Kualitas Produk, Harga, Promosi, Atribut Produk dan Keputusan pembelian

\begin{abstract}
,
This research was conducted with the aim to determine the effect of product quality, price, promotion and product attributes on the purchasing decisions of pepsodent toothpaste on students of Islamic economics majors at the IAIN faculty of economics and Islamic business at the meeting level. This research is quantitative research. The sample used in this study was 92 people. Data collection techniques used were questionnaire techniques and observations for completeness of the data in this study. Analysis using statistics, namely SPSS version 22. The results of the analysis of determination coefficient $(R)$ can be seen that the value of $r=0.727$ means that the correlation between product quality, price, promotion and product attributes on purchasing decisions has a strong relationship. The Adjusted R2 value of 0.507 or $50.7 \%$ indicates that product quality, price, promotion and product attributes variables influence purchasing decisions and the remaining $49.3 \%$ is influenced by
\end{abstract}




\section{PENGARUH KUALITAS PRODUK, HARGA, PROMOSI DAN ATRIBUT PRODUK TERHADAP KEPUTUSAN PEMBELIAN PASTA GIGI PEPSODENT PADA MAHASISWA JURUSAN EKONOMI SYARIAH FAKULTAS EKONOMI DAN BISNIS ISLAM IAIN PADANGSIDIMPUAN}

other factors outside of the research conducted by the researcher. Based on the results of this study there is an influence of product quality on purchasing decisions of pepsodent toothpaste with a value of tcount $>t$ table $(5,111>1,663)$. The price variable has an influence on the purchasing decision of pepsodent toothpaste with a value $(1,670>1,663)$. Promotional variables have an influence on the purchasing decision of pepsodent toothpaste with a value (1.755> 1.663). Product attribute variables have an influence on pepsodent toothpaste purchasing decisions with a value $(4,552>1,663)$. It can be concluded that there is a significant influence between the variables of product quality, price, promotion and product attributes on the purchasing decisions of pepsodent toothpaste in the Students of the Department of Islamic Economics, Faculty of Economics and Islamic Business, IAIN Padangsidimpuan.

Keywords: Product Quality, Price, Promotion, Product Attributes and Purchasing Decisions

\section{PENDAHULUAN}

Dalam kehidupan banyak manusia yang menginginkan kesehatan, baik kesehatan jasmani maupun kesehatan rohani.Mahasiswa Jurusan Ekonomi Syariah Fakultas Ekonomi dan Bisnis Islam IAIN Padangsidimpuan merupakan konsumen bagi perusahaan, salah satu adalah konsumen pasta gigi, karena bagi Mahasiswa menjaga kesehatan itu penting.Pasta gigi merupakan kebutuhan yang sangat penting bagi pemeliharaan dan kesehatan gigi.Satu hal yang harus dicermati, peranan gigi bukan hal yang sepele terhadap kesehatan tubuh secara keseluruhan (Melanie Sadono Djamil, 2003). Dalam hal ini tidak kalah pentingnya menjaga kesehatan gigi.Kesehatan gigi merupakan hal yang sangat berpengaruh dalam kehidupan sehari-hari.Maka dari itu pentingnya menjaga kesehatan gigi dengan selalu menggosok gigi secara teratur, hal ini bisa dilakukan dengan menggunakan pasta gigi untuk membersihkan kotoran yang berada di dalam mulut seseorang.Mahasiswa harus selalu menjaga kesegaran nafasnya dalam hal berkomunikasi dengan dosen maupun dengan orang lain. Makin sering orang menggososk gigi makin baik bagi kesehatan (Su'dan, R. H., 1997).

Dari berbagai merek pasta gigi yang beredar dipasaran yang bisa didapati oleh masyarakat dan juga kalangan Mahasiswa Jurusan Ekonomi Syariah untuk dibeli seperti Close up, Ciptadent, Formula, dan Pepsodent.Perusahaan pasta gigi brend name sering kali 
melakukan trobosan-trobosan dalam berinovasi.Inovasi merupakan kunci keberhasilan bagi perusahaan, inovasi yang terus-menerus merupakan suatu kekuatan bagi perusahaan untuk meraih kesuksesan bagi perusahaan tersebut (Suryana, 2013).

Perubahan pasar yang sangat cepat dan persaingan yang kompleks menuntut inovasi secara terus-menerus atau berkesinambungan. Bentuk inovasi yang lazim dan terkenal ialah bentuk inovasi dalam produk baru, perbedaan tehnik atau cara, dan pendekatan baru dalam memperkenalkannya. Pepsodent tidak hanya mengeluarkan produk pasta gigi yang hanya untuk menyegarkan nafas dan memutihkan gigi saja, tetapi perusahaan pepsodent juga terus berinovasi mengikuti permintaan dari apa yang dibutuhkan oleh gigi konsumen, masingmasing mempunyai varian yang berbeda-beda yang dikeluarkan oleh pasta gigi pepsodent, fungsi yang berbeda agar manfaat yang didapat akan lebih maksimal, misalnya seperti pepsodent sensitive expert whitening (yang mengerti akan gigi sensitiv), pepsodent action 123 (pencegah gigi berlubang, gigi tampak putih dan nafas lebih segar, dan masih banyak lagi varian lainnya.

Peneliti melakukan survei awal di IAIN Padangsidimpuan sebanyak 112 responden. Berdasarkan survei yang dilakukan, merek pasta gigi yang digunakan Mahasiswa Jurusan Ekonomi Syariah dapat dilihat pada tabel berikut ini: 
PENGARUH KUALITAS PRODUK, HARGA, PROMOSI DAN ATRIBUT PRODUK TERHADAP KEPUTUSAN PEMBELIAN PASTA GIGI PEPSODENT PADA MAHASISWA JURUSAN EKONOMI SYARIAH FAKULTAS EKONOMI DAN BISNIS ISLAM IAIN PADANGSIDIMPUAN

Tabel I.1

Hasil Observasi Awal

Pada Mahasiswa Jurusan Ekonomi Syariah

\begin{tabular}{|c|c|c|c|}
\hline $\begin{array}{c}\text { Jumlah } \\
\text { Responden }\end{array}$ & Pilihan Merek Pasta Gigi & Jumlah & Alasan \\
\hline \multirow[t]{2}{*}{112 Responden } & Pepsodent & 96 & $\begin{array}{l}\text { 1. kualitas produk } \\
\text { 2. Harga } \\
\text { 3. Promosi } \\
\text { 4. Atribut produk }\end{array}$ \\
\hline & $\begin{array}{l}\text { Close Up } \\
\text { Ciptadent } \\
\text { Formula }\end{array}$ & $\begin{array}{l}11 \\
1 \\
2\end{array}$ & \\
\hline
\end{tabular}

Sumber: Hasil Survei (data diolah)

Dari hasil survei awal yang dilakukan peneliti kepada 112 responden tersebut, Mahasiswa Jurusan Ekonomi Syariah di IAIN Padangsidimpuan lebih banyak membeli pasta gigi pepsodent dengan alasan memilih karena kualitas produk, harga, promosi dan atribut produkdibandingkan pasta gigi lainnya. Keputusan pembelian yang dilakukan Mahasiswa Jurusan Ekonomi Syariah terhadap produk pasta gigi pepsodent dikarenakan faktor yaitu, kualitas, harga, promosi dan atribut produk.

Setiap perusahaan yang bergerak dalam dunia kesehatan gigi berlomba-lomba untuk meningkatkan produksinya, karena itu merupakan prasyarat bagi perusahaan dalam mempertahankan kualitas produknya.kualitas adalah kepuasan pelanggan sepenuhnya. Suatu produk berkualitas apabila dapat memberi kepuasan sepenuhnya kepada konsumen, yaitu sesuai dengan apa yang diharapkan konsumen atas suatu produk (M.N. Nasution, 2010). Produk membutuhkan kemasan agar tercipta manfaat-manfaat tertentu seperti misalnya 
perlindungan, kemudahan, manfaat ekonomi dan promosi.Kemasan harus menarik perhatian karena kemasan menggambarkan citra merek tersebut.

Komponen lain dari kualitas yang tidak kalah pentingnya adalah harga yang murah dan merek yang terkenal. Perusahaan harus selalu mengamati harga yang ditetapkan oleh para pesaing agar harga yang ditentukan oleh perusahaan tersebut tidak terlalu tinggi atau sebaliknya.Harga selain merupakan jalan masuknya uang ke perusahaan, juga berhubungan dengan kualitas produk.Konsumen memandang harga sebagai indikator kualitas produk, terutama jika mereka harus mengambil keputusan membeli dengan informasi yang tidak lengkap.Dengan demikian produk dengan harga yang lebih mahal dianggap berkualitas lebih baik (Mahmud Machfoedz, 2007).

Dari segi harga dan kualitas itu tidak cukup untuk meyakinkan konsumen untuk dapat mengenal produk yang diciptakan dengan segala keunggulannya, maka perusahaan perlu menerapkan strategi promosi.Promosi dipandang sebagai arus informasi yang dibuat untuk mengarahkan seseorang atau organisasi agar melakukan pertukaran dalam pemasaran.Disinilah perlunya mengadakan promosi yang terarah, dengan promosi yang terarah dihapkan dapat memberikan pengaruh yang positif terhadap penjualan.

Menurut konsep pemsaran, perusahaan tersebut harus menjadi lebih efektif dalam menciptakan produk dan mampu menawarkan nilai lebih dan sesuai dengan keinginan pelanggan dibandingkan para pesaingnya (Pjilip Kotler dan Kevin Keller, 2007). Pemasar harus memahami bagaimana proses keputusan konsumen dan alasan pembelian yang tidak sama di antara berbagai tipe konsumen. Dengan demikian, setiap perusahaan harus mengetahui terlabih dahulu tentang apa yang dibeli, bagaimana kebiasaannya, dalam kondisi seperti apa barang dan jasa dibeli oleh konsumen, siapa saja yang membutuhkan, berapa yang dibutuhkan oleh konsumen serta mengapa konsumen memilih produk tersebut. 


\section{PENGARUH KUALITAS PRODUK, HARGA, PROMOSI DAN ATRIBUT PRODUK TERHADAP KEPUTUSAN PEMBELIAN PASTA GIGI PEPSODENT PADA MAHASISWA JURUSAN EKONOMI SYARIAH FAKULTAS EKONOMI DAN BISNIS ISLAM IAIN PADANGSIDIMPUAN}

Berbagai penelitian telah dilakukan untuk mengkaji manfaat yang bisa dipetik dari pengaruh kualitas produk, harga, promosi terhadap keputusan pembelian.Dalam penelitian Novemy Triyandari Nugroho menyimpulkan bahwa, "kualitas produk berpengaruh signifikan terhadap keputusan pembelian air mineral kemasan.Harga berpengaruh secara signifikan terhadap keputusan pembelian air mineral kemasan. Promosi berpengaruh secara signifikan terhadap keputusan pembelian air mineral kemasan” (Novemy Triyandari Nugroho, 2015).

Bedasarkan uraian diatas, peneliti tertarik untuk melakukan penelitian kualitas produk, harga dan promosi.Dalam penelitian ini berjudul "Pengaruh Kualitas Produk, Harga, Promosi dan Atribut Produk Terhadap Keputusan Pembelian Pasta Gigi Pepsodent pada Mahasiswa Jurusan Ekonomi Syariah Fakultas Ekonomi dan Bisnis Islam IAIN Padangsidimpuan".

\section{TINJAUAN TEORITIK}

\section{Keputusan pembelian}

Pemahaman yang paling umum, sebuah keputusan adalah seleksi terhadap dua pilihan alternatif atau lebih. Dengan perkataan lain, pilihan alternatif harus bersedia bagi seseorang ketika mengambil keputusan. Jika seseorang mempunyai pilihan antara melakukan pembelian dan tidak melakukan pembelian orang tersebut berada dalam posisi mengambil keputusan Leon Schiffman dan Leslie Lazar Kanuk. Menurut Schiffman dan Kanuk mengatakan dalam buku UjangSumarwan, "suatu keputusan sebagai pemilihan suatu tindakan dari dua atau lebih pilihan alternatif. Seorang konsumen yang hendak melakukan pilihan maka ia harus memiliki pilihan alternatif" (Ujang Sumarwan, 2011).

Pengambilan keputusan adalah proses memilih suatu alternatif cara bertindak dengan metode yang efisien sesuai situasi. Pengambilan keputusan adalah suatu pendekatan yang 
sistematis terhadap hakikat alternatif yang dihadapi dan mengambil tindakan yang menurut perhitungan merupakan tindakan yang paling tepat (Nugroho J Setiadi, 2008).

Dari berbagai pemahaman di atas peneliti dapat menyimpulkan bahwa pengambilan keputusan merupakan proses pemilihan alternatif terbaik dari beberapa alternatif secara sistematis untuk ditindaklanjuti atau digunakan sebagai cara pemecahan masalah. Proses itu untuk menemukan dan menyelesaikan masalah organisasi. Pernyataan ini menegaskan bahwa mengambil keputusan memerlukan satu seri tindakan yang membutuhkan beberapa langkah.

a. Peran Dalam Pembelian

Ada empat peran yang dimainkan orang dalam suatu keputusan pembelian yaitu: (Pandji Anaroga, 2009).

1) Pengambil inisiatif (initiator), yaitu seseorang yang pandangannya atau sarannya diperhitungkan dalam pengambilan keputusan.

2) Orang yang mempengaruhi (influencer), yaitu seseorang yang memutuskan sebagian besar keputusan membeli, seperti: apakah jadi membeli, apa yang dibeli, bagaimana membelinya, atau dimana membelinya.

3) Pembeli (buyer), yaitu seseorang yang melakukan pembelian yang sebenarnya.

4) Pemakai (user), yaitu seseorang yang mengkonsumsi atau menggunakan barang atau jasa yang dibeli.

b. Tahap-tahap Dalam Pengambilan keputusan

Tahapan untuk mencapai keputusan membeli dilakukan oleh konsumen melalui beberapa tahapan, meliputi: mengenali kebutuhan, mencari informasi, evaluasi alternatif, keputusan membeli, dan perilaku setelah pembelian. Tahapantahapan tersebut dapat diilustrasikan dalam bagan gambar: (Mahmud Machfoed, 2007) 
PENGARUH KUALITAS PRODUK, HARGA, PROMOSI DAN ATRIBUT PRODUK TERHADAP KEPUTUSAN PEMBELIAN PASTA GIGI PEPSODENT PADA MAHASISWA JURUSAN EKONOMI SYARIAH FAKULTAS EKONOMI DAN BISNIS ISLAM IAIN PADANGSIDIMPUAN

Gambar II.1

Proses Keputusan Pembelian

Mengenali
Kebutuhan $\rightarrow \begin{gathered}\text { Mencari } \\ \text { Informasi }\end{gathered} \rightarrow \begin{gathered}\text { Evaluasi } \\ \text { Alternatif }\end{gathered} \rightarrow \begin{gathered}\text { Keputusan } \\ \text { Membeli }\end{gathered} \rightarrow \begin{gathered}\text { Perilaku Pasca } \\ \text { Pembelian }\end{gathered}$

Gambar diatas menunjukkan bahwa konsumen melalui lima tahapan setiap kali

melakukan pembelian. Namun dalam praktik pembelian yang dilakukan secara rutin, tidak jarang konsumen mengabaikan atau melakukan tindakan yang berlawanan dengan beberapa tahapan tersebut. Seseorang yang membeli susu kesukaannya akan mengingat kebutuhan tersebut dan langsung mengambil keputusan untuk membeli dengan mengabaikan pencarian informasi dan evaluasi alternatif. Meskipun demikian, model dalam gambar tersebut tetap berlaku karena gambar ini menunjukkan semua pertimbangan yang terjadi ketika konsumen akan membeli produk baru dan berada dalam kondisi pembelian yang kompleks.

\section{Konsep Kualitas Produk}

Kualitas merupakan seberapa baik sebuah produk sesuai dengan kebutuhan spesifik dari pelanggan. Kualitas meliputi kualitas kinerja, kualitas kesesuaian, daya tahan dan keandalan. Kualitas kinerja mengacu pada tingkat di mana karakteristik produk itu beroperasi. Kualitas kesesuaian merupakan tingkat di mana semua unit yang diproduksi identik dan memenuhi spesifikasi sasaran yang dijanjikan. Daya tahan adalah suatu ukuran usia operasi produk yang diharapkan dalam kondisi normal atau berat. Keandalan merupakan ukuran suatu produk tidak akan rusak atau gagal dalam periode tertentu (M. Suyanto, 2007).

Dalam pemasaran syariah, produk merupakan karunia yang terbaik dari tuhan pada manusia. Produk dinyatakan dalam dua istilah, yaitu Al-tayyibat dan Al-rizq. Al-tayyibat merujuk pada suatu baik, suatu yang murni dan baik, sesuatu yang bersih dan murni, sesuatu yang baik dan menyeluruh serta makanan yang terbaik. Al-rizq merujuk pada makanan yang diberkahi tuhan, pemberian yang menyenangkan dan ketetapan tuhan. Produk dalam 
pemasaran syraiah adalah produk yang dapat dipertukarkan dan berdaya guna secara moral (M. Suyanto, 2007).

Kualitas produk adalah kecocokan penggunaan produk (fitness for use) untuk memenuhi kebutuhan dan kepuasan pelanggan.kualitas adalah kepuasan pelanggan sepenuhnya. Suatu produk berkualitas apabila memberikan kepuasan sepenuhnya kepada konsumen, yaitu sesuai dengan apa yang diharapkan konsumen atas suatu produk.

Menurut Deming dalam M. N. Nasution menyatakan bahwa, "kualitassebagai kesesuaian dengan kebutuhan pasar atau konsumen. Perusahaan harus benar-benar dapat memahami apa yang dibutuhkan konsumen atas suatu produk yang akan dihasilkan" (M. N. Nasuiton, 2010).

Crosby dalam M. N. Nasasution menyatakan, bahwa "kualitas adalah (conformance to requirement), yaitu sesuai dengan yang disyaratkan atau distandarkan. Suatu produk memiliki kualitas apabila sesuai dengan standar kualitas yang telah ditentukan" (M. N. Nasuiton, 2010).

Dari beberapa pengertian di atas dapat disimpulkan bahwa, kualitas produk adalah kepuasan pelanggan sepenuhnya. Suatu produk berkualitas apabila dapat member kepuasan sepenuhnya kepada konsumen, yaitu sesuai dengan apa yang diharapkan konsumen atas suatu produk. Selera pribadi tidak dapat dipisahkan dari penilaian kualitas suatu produk. Disamping selera pribadi, harapan individu juga berpengaruh terhadap ketetapan tentang kualitas.

\section{Strategi Harga}

Harga dalam bauran pemasaran mengacu pada apa yang harus diberikan konsumen untuk membeli suatu barang atau jasa yang biasanya menggunakan nilai uang. Harga suatu produk ditentukan tidak saja berdasarkan biaya produksi namun juga faktor-faktor lain, seperti tingkat permintaan terhadap produk bersangkutan, tingkat persaingan, serta persepsi konsumen terhadap produk.Harga adalah sejumlah nilai yang ditukarkan konsumen dengan manfaat memiliki atau menggunakan produk yang nilainya ditetapkan oleh pembeli dan 
PENGARUH KUALITAS PRODUK, HARGA, PROMOSI DAN ATRIBUT PRODUK TERHADAP KEPUTUSAN PEMBELIAN PASTA GIGI PEPSODENT PADA MAHASISWA JURUSAN EKONOMI SYARIAH FAKULTAS EKONOMI DAN BISNIS ISLAM IAIN PADANGSIDIMPUAN

penjual melalui tawar-menawar, atau ditetapkan oleh penjual untuk satu harga yang sama terhadap semua pembeli (Husein Umar, 2013).

Penentuan harga merupakan salah satu aspek penting dalam kegiatan pemasaran.Penentuan harga menjadi sangat penting untuk diperhatikan mengingat harga merupakan salah satu penyebab laku tidaknya produk dan jasa yang ditawarkan. Salah dalam menentukan harga dalam akan berakibat fatal terhadap produk yang ditawarkan dan berakibat tidak lakunya produk tersebut dipasar.Penetapan harga dan persaingan harga telah dinilai sebagai masalah utama yang dihadapi perusahaan. Keputusan-keputusan mengenai harga dipengaruhi oleh berbagai faktor, yaitu faktor internal dan faktor eksternal (Agus Sucipto, 2011).

Faktor internal, keputusan harga disesuaikan dengan sasaran pemasaran, misalnya: sasarannya adalah untuk bertahan hidup yaitu dengan menentukan harga semurah mungkin dengan maksud produk yang ditawarkan laku dipasaran, harga murah tapi dalam kondisi yang menguntungkan.Faktor eksternal, yaitu pasar dan permintaan konsumen merupakan plafon harga (harga tinggi). Konsumen akan membandingkan harga suatu produk dengan manfaat yang dimilikinya. Oleh karena itu dalam menetapkan harga harus dipahami dulu hubungan antara harga dan permintaan terhadap suatu produk.Harga tawaran kompetitor perlu diketahui untuk menentukan harga sera reaksi mereka setelah keputusan harga diberlakukan (Agus Sucipto, 2011).

Dari beberapa pengertian di atas peneliti menyimpulkan bahwa perusahaan perlu memonitor harga yang ditetapkan oleh para pesaing agar harga yang ditentukan oleh perusahaan tersebut tidak terlalu tinggi atau sebaliknya. Penentuan harga yang akan ditetapkan harus disesuaikan dengan tujuan perusahaan.

\section{Promosi}


Istilah promosi sudah sering kita dengar dalam kehidupan ini. Kata atau istilah ini sering digunakan saat ada produsen yang akan menjual produk atau jasanya dengan cara terlebih dahulu membuat produk atau jasanya dikenal oleh masyarakat luas. Supaya dapat dikenal oleh masyarakat atau konsumen maka dilakukan kegiatan promosi.

Promosi adalah salah satu bagian dari bauran pemasaran yang besar peranannya. Promosi merupakan suatu ungkapan dalam arti luas tentang kegiatan-kegiatan yang secara aktif dilakukan oleh perusahaan (penjual) untuk mendorong konsumen membeli produk yang ditawarkan M. Fuad dkk, 2000). Menurut Suryana, "promosi adalah cara mengkomunikasikan barang atau jasa yang ditawarkan supaya konsumen mengenal dan membeli. Tujuan promosi adalah untuk memperkenalkan barang atau jasa agar diketahui , dibutuhkan dan diminta oleh konsumen".

Dari beberapa pemahaman diatas peneliti dapat menyimpulkan bahwa promosi merupakan kegiatan pemasaran yang terakhir, kegiatan ini sama pentingnya dengan ketiga kegiatan di atas, baik kualitas, harga maupun atribut produknya. Tanpa promosi pelanggan tidak dapat mengenal produk atau jasa yang ditawarkan. Oleh karena itu, promosi merupakan sarana yang paling ampuh untuk menarik dan mempertahankan konsumen.

\section{Atribut Produk}

Atribut sangat berbeda dalam hal kepentingannya bagi para konsumen. Pentingnya atribut didefinisikan sebagai penilaian umum seseorang terhadap signifikansi atribut atas produk atau jasa tertentu. Pendekatan ini menggunakan perspektif pemrosesan informasi, yang berargumentasi bahwa pentingnya atribut secara langsung dipengaruhi oleh perhatian konsumen terhadap atribut. Jadi, semakin besar perhatian yang diarahkan pada atribut, semakin penting atribut itu (Etta Mamang Sangadji dan Sopiah, 2013).

Menurut Philip Kotler dalam buku Kasmir, "Produk adalah sesuatu yang dapat ditawarkan ke pasar untuk mendapatkan perhatian untuk dibeli, digunakan atau dikonsumsi 
PENGARUH KUALITAS PRODUK, HARGA, PROMOSI DAN ATRIBUT PRODUK TERHADAP KEPUTUSAN PEMBELIAN PASTA GIGI PEPSODENT PADA MAHASISWA JURUSAN EKONOMI SYARIAH FAKULTAS EKONOMI DAN BISNIS ISLAM IAIN PADANGSIDIMPUAN

sehingga dapat memenuhi keinginan dan kebutuhan”.Menurut Fandy Tjiptono, “atribut produk adalah unsur-unsur produk yang dipandang penting oleh konsumen dan dijadikan dasar pengambilan keputusan pembelian” Fandy Tjiptono, 1997).

Dalam konsep produk perlu dipahami tentang wujud dari produk tersebut. Wujud produk menunjukkan ciri untuk apa suatu produk dibeli atau dikonsumsi. Dari wujud fisik inilah, konsumen atau pembeli membedakan satu produk dengan produk lain, sehingga menarik motivasi konsumen atau pola pembeliannya. Karena wujud fisik dari produk sangat penting peranannya dalam pemasaran, maka perlu diusahakan agar produk tersebut mempunyai penampilan, gaya dan warna yang menarik dengan ukuran yang tepat. Dari pengertian tersebut dapat disimpulkan bahwa Atribut yang dipandang bagus akan mendorong seseorang untuk mengambil keputusan terhadap produk tersebut.

\section{Hipotesis}

Hipotesis merupakan hubungan yang diperkirakan secara logis di antara dua atau lebih variabel yang diungkap dalam bentuk pernyataan yang dapat diuji. Hipotesis merupakan jawaban sementara terhadap rumusan masalah penelitian, di mana rumusan masalah penelitian telah dinyatakan dalam bentuk kalimat pertanyaan (Sugiyono, 2013). Dikatakan sementara, karena jawaban yang diberikan baru berdasarkan pada teori yang relevan, belum didasarkan pada fakta-fakta empiris yang diperoleh melalui pengumpualan data. Jadi hipotesis juga dapat dinyatakan sebagai jawaban teoritis terhadap rumusan masalah penelitian, belum jawaban yang empirik. Dalam penelitian ini hipotesis adalah sebagai berikut: 
1) $\mathrm{Ha}_{1}$ : Ada pengaruh kualitas produk $\left(\mathrm{X}_{1}\right)$ terhadap keputusan pembelian $(Y)$ pasta gigi pepsodent pada Mahasiswa Jurusan Ekonomi Syariah Fakultas Ekonomi Dan Bisnis Islam IAIN Padangsidimpuan.

2) Ha2: Ada pengaruh harga $\left(\mathrm{X}_{2}\right)$ terhadap keputusan pembelian (Y) pasta gigi pepsodent pada Mahasiswa Jurusan Ekonomi Syariah Fakultas Ekonomi Dan Bisnis Islam IAIN Padangsidimpuan.

3) Ha3: Ada pengaruh promosi $\left(\mathrm{X}_{3}\right)$ terhadap keputusan pembelian (Y) pasta gigi pepsodent pada Mahasiswa Jurusan Ekonomi Syariah Fakultas Ekonomi Dan Bisnis Islam IAIN Padangsidimpuan.

4) $\mathrm{Ha}_{4}$ : Ada pengaruh atribut produk $\left(\mathrm{X}_{4}\right)$ terhadap keputusan pembelian (Y) pasta gigi pepsodent pada Mahasiswa Jurusan Ekonomi Syariah Fakultas Ekonomi Dan Bisnis Islam IAIN Padangsidimpuan.

5) Has: Ada pengaruh kualitas produk, harga, promosi dan atribut produk (X) terhadap keputusan pembelian(Y) pasta gigi pepsodent pada Mahasiswa Jurusan Ekonomi Syariah Fakultas Ekonomi Dan Bisnis Islam IAIN Padangsidimpuan.

\section{METODE PENELITIAN}

Analisis regresi linear berganda mempunyai langkah yang hampir sama dengan analisis regresi linear sederhana. Yang menjadi pembeda antara kedua terletak pada variabel yang dimiliki peneliti.Analisis regresi adalah kelanjutan setelah uji validitas, realibilitas, dan uji asumsi klasik.Analisis regresi linear berganda merupakan persamaan regresi dengan menggunakan dua atau lebih variabel independen. Bentuk persamaan regresi linear berganda ini adalah: (Duwi Priyatno, 2014)

$$
Y=a+b_{1} X_{1}+b_{2} X_{2}+b_{3} X_{3}+b_{4} X_{4}+e
$$

Keterangan:

$\mathrm{Y} \quad=$ Keputusan pembelian 
PENGARUH KUALITAS PRODUK, HARGA, PROMOSI DAN ATRIBUT PRODUK TERHADAP KEPUTUSAN PEMBELIAN PASTA GIGI PEPSODENT PADA MAHASISWA JURUSAN EKONOMI SYARIAH FAKULTAS EKONOMI DAN BISNIS ISLAM IAIN PADANGSIDIMPUAN

$\mathrm{B}=$ Konstanta perubahan variabel $\mathrm{X}$ terhadap $\mathrm{Y}$

a $\quad=$ Koefisien konstanta

$b_{1} b_{2} b_{3} b_{4}=$ Koefisien regresi linier berganda

e $\quad$ Tingkat error

Sehingga rumus dalam penelitian ini adalah sebagai berikut:

$$
\mathrm{KP}=\mathrm{a}+\mathrm{b}_{1} \text { Kualitas produk }+\mathrm{b}_{2} \text { Harga }+\mathrm{b}_{3} \text { Promosi }+\mathrm{b}_{4} \text { Atribut produk }+\mathrm{e}
$$

\section{Pengujian Asumsi Klasik}

Uji asumsi klasik digunakan untuk menguji normalitas data penelitian, uji multokilinearitas, uji heteroskedastisitas dan uji autokorelasi. Menurut (Sugiono dan Susanto, 2015), uji normalitas bertujuan untuk menguji data penelitian baik variabel dependen maupun variabel independen terdistribusi normal atau tidak dengan menggunakan kolmogrov-smirnow pada taraf signifikan 0,1. Dan uji multikolinieritas digunakan untuk melihat adanya hubungan linier sempurna diantara variabel independennya dengan melihat nilai VIF (Variance Inflasion Factor). Dan uji heteroskedastisitas digunakan untuk mengetahui ada atau tidaknya penyimpangan asumsi klasik melalui penyebaran titik yang tidak membentuk pola. Dan mengukur uji autokorelasi dengan melihat hasil uji Durbin-Watson (DW).

\section{Pengujian Hipotesis}

Uji hipotesis digunakan untuk mengukur besarnya pengaruh variabel independen terhadap variabel dependen. Untuk mengukur seberapa jauh kemampuan model dalam menerangkan variasi dependen digunakan uji koefisien determinasi $\left(\mathrm{R}^{2}\right)$, menurut (Setiawan dan Kusrini, 2010), nilai yang mendekati satu berarti variabel-variabel independen memberikan hampir semua informasi yang dibutuhkan untuk memprediksi variasi variabel dependen. Untuk mengetahui apakah ada model regresi variabel independen secara parsial berpengaruh signifikan terhadap variabel dependen, maka digunakanlah uji $t$, menurut (Siregar, 2014), kaidah pengujian untuk menguji secara parsial yaitu jika $T_{\text {hitung }} \leq \mathrm{T}_{\text {tabel }}$ maka $\mathrm{H}_{\mathrm{o}}$ diterima dan $\mathrm{H}_{\mathrm{a}}$ ditolak, dan jika $\mathrm{T}_{\text {hitung }} \geq \mathrm{T}_{\text {tabel }}$ maka $\mathrm{H}_{\mathrm{o}}$ ditolak dan $\mathrm{H}_{\mathrm{a}}$ diterima. Dan untuk mengetahui pengaruh semua variabel independen terhadap variabel dependen maka digunakanlah uji $\mathrm{F}$, uji ini dilakukan dengan syarat bila $\mathrm{F}_{\text {hitung }}<\mathrm{F}_{\text {tabel }}$ maka $\mathrm{H}_{\mathrm{o}}$ diterima dan $\mathrm{H}_{\mathrm{a}}$ ditolak, bila $\mathrm{F}_{\text {hitung }}>\mathrm{F}_{\text {tabel }}$ maka $\mathrm{H}_{\mathrm{o}}$ ditolak dan $\mathrm{H}_{\mathrm{a}}$ diterima.

\section{HASIL DAN PEMBAHASAN}

Sebelum melakukan analisis data, terlebih dahulu menentukan uji normalitas dari data penelitian, adapun hasil uji normalitas penelitian ini adalah : 
Volume 6 Nomor 1 Ed. Januari-Juni 2018 : hal. 58-81

p-ISSN: 2356-4628 e-ISSN : 2579-8650

Tabel 1

Hasil Uji Normalitas

One-Sample Kolmogorov-Smirnov Test

\begin{tabular}{|ll|r|}
\hline & & Unstandardized Residual \\
\hline $\mathrm{N}$ & & 92 \\
Normal Parameters ${ }^{\mathrm{a}, \mathrm{b}}$ & Mean & .0000000 \\
& Std. Deviation & 3.41151346 \\
Most Extreme Differences & Absolute & .083 \\
& Positive & .053 \\
& Negative & -.083 \\
Test Statistic & & .083 \\
Asymp. Sig. (2-tailed) & & $.153^{\mathrm{c}, \mathrm{d}}$ \\
\hline
\end{tabular}

Hasil uji normalitas pada tabel 1 dapat dilihat bahwa nilai signifikansi (Asymp.Sig 2tailed) sebesar 0,153.Nilaisignifikansi lebih dari $0,10(0,153>0,10)$, maka dapat disimpulkan bahwa nilai residual tersebut berdistribusi normal. Sehingga data tersebut memenuhi syarat untuk uji parametrik.

Tabel 2

Hasil Uji Multikolinearitas

Coefficients $^{\mathrm{a}}$

\begin{tabular}{|c|c|c|c|c|c|c|c|}
\hline \multirow[b]{2}{*}{ Model } & \multicolumn{2}{|c|}{$\begin{array}{c}\text { Unstandardized } \\
\text { Coefficients }\end{array}$} & \multirow{2}{*}{$\begin{array}{c}\text { Standardized } \\
\text { Coefficients } \\
\text { Beta } \\
\end{array}$} & \multirow[b]{2}{*}{$\mathrm{T}$} & \multirow[b]{2}{*}{ Sig. } & \multicolumn{2}{|c|}{$\begin{array}{c}\text { Collinearity } \\
\text { Statistics }\end{array}$} \\
\hline & $B$ & $\begin{array}{l}\text { Std. } \\
\text { Error }\end{array}$ & & & & $\begin{array}{c}\text { Toleran } \\
\text { ce }\end{array}$ & VIF \\
\hline (Constant) & -3.765 & 4.141 & & -.909 & .366 & & \\
\hline $\begin{array}{l}\text { Kualitas_Pr } \\
\text { oduk }\end{array}$ & .467 & .091 & .421 & 5.111 & .000 & .799 & 1.25 \\
\hline Harga & .149 & .089 & .123 & 1.670 & .099 & .994 & 1.00 \\
\hline Promosi & .164 & .093 & .146 & 1.755 & .083 & .782 & $\begin{array}{r}1.27 \\
9\end{array}$ \\
\hline $\begin{array}{l}\text { Atribut_Pro } \\
\text { duk }\end{array}$ & .455 & .100 & .369 & 4.552 & .000 & .824 & $\begin{array}{r}1.21 \\
4 \\
\end{array}$ \\
\hline
\end{tabular}

a. Dependent Variable: Keputusan_Pembelian

Sumber: Data diolah dari hasil output SPSS 22

Hasil uji multikolinearitas pada tabel 2, dapat diketahui bahwa nilai VIF dari variabel kualitas produk adalah 1,252, variabel harga adalah 1,006, variabel promosi adalah 1,279 dan variabel atribut produk adalah 1,214. Maka dapat disimpulkan bahwa nilai VIF dari keempat variabel di atas lebih kecil< 10 .Nilaitolerance untuk variabel kualitas produk adalah 0,799 , 
PENGARUH KUALITAS PRODUK, HARGA, PROMOSI DAN ATRIBUT PRODUK TERHADAP KEPUTUSAN PEMBELIAN PASTA GIGI PEPSODENT PADA MAHASISWA JURUSAN EKONOMI SYARIAH FAKULTAS EKONOMI DAN BISNIS ISLAM IAIN PADANGSIDIMPUAN

variabel harga adalah 0,994, variabel promosi adalah 0,782dan untuk variabel atribut produk adalah 0,824.Jadi dapat disimpulkan bahwa nilai tolerancedari keempat variabel $>0,1$.Berdasarkan penilaian tersebut dapat disimpulkan tidak terjadi multikolinearitas antara variabel bebas.

Tabel 3 Hasil Uji Heteroskedastisitas

\begin{tabular}{|c|c|c|c|c|c|c|}
\hline \multicolumn{7}{|c|}{ Correlations } \\
\hline & & $\begin{array}{r}\text { Kualitas } \\
\text { Produk }\end{array}$ & Harga & Promosi & $\begin{array}{l}\text { Atribut_ } \\
\text { Produk }\end{array}$ & $\begin{array}{l}\text { Unstandardi } \\
\text { zed } \\
\text { Residual }\end{array}$ \\
\hline $\begin{array}{l}\text { Kualitas } \\
\text { _Produk }\end{array}$ & $\begin{array}{l}\text { Correlation } \\
\text { Coefficient } \\
\text { Sig. (2-tailed) } \\
\mathrm{N}\end{array}$ & $\begin{array}{r}1.000 \\
. \\
92 \\
\end{array}$ & $\begin{array}{r}.252^{*} \\
.015 \\
92 \\
\end{array}$ & $\begin{array}{r}.380^{* *} \\
.000 \\
92 \\
\end{array}$ & $\begin{array}{r}.314^{\star *} \\
.002 \\
92 \\
\end{array}$ & $\begin{array}{r}-.161 \\
.126 \\
92 \\
\end{array}$ \\
\hline Harga & $\begin{array}{l}\text { Correlation } \\
\text { Coefficient } \\
\text { Sig. (2-tailed) } \\
\mathrm{N}\end{array}$ & $\begin{array}{r}.252^{*} \\
.015 \\
92 \\
\end{array}$ & 92. & $\begin{array}{r}.056 \\
.593 \\
92 \\
\end{array}$ & $\begin{array}{r}-.017 \\
.872 \\
92 \\
\end{array}$ & $\begin{array}{r}-.026 \\
.808 \\
92 \\
\end{array}$ \\
\hline Promosi & $\begin{array}{l}\text { Correlation } \\
\text { Coefficient } \\
\text { Sig. (2-tailed) } \\
\mathrm{N}\end{array}$ & $\begin{array}{r}.380^{* *} \\
.000 \\
92 \\
\end{array}$ & $\begin{array}{r}.056 \\
.593 \\
92 \\
\end{array}$ & 92. & $\begin{array}{r}.567^{* *} \\
.000 \\
92 \\
\end{array}$ & $\begin{array}{r}-.163 \\
.120 \\
92 \\
\end{array}$ \\
\hline $\begin{array}{l}\text { Atribut__ } \\
\text { Produk }\end{array}$ & $\begin{array}{l}\text { Correlation } \\
\text { Coefficient } \\
\text { Sig. (2-tailed) } \\
\mathrm{N}\end{array}$ & $\begin{array}{r}.314^{* *} \\
.002 \\
92 \\
\end{array}$ & $\begin{array}{r}-.017 \\
.872 \\
92 \\
\end{array}$ & $\begin{array}{r}.567^{\star *} \\
.000 \\
92 \\
\end{array}$ & $\begin{array}{r}1.000 \\
. \\
92 \\
\end{array}$ & $\begin{array}{r}-.087 \\
.411 \\
92 \\
\end{array}$ \\
\hline $\begin{array}{l}\text { Unstand } \\
\text { ardized } \\
\text { Residual }\end{array}$ & $\begin{array}{l}\text { Correlation } \\
\text { Coefficient } \\
\text { Sig. (2-tailed) } \\
\mathrm{N}\end{array}$ & $\begin{array}{r}-.161 \\
.126 \\
92\end{array}$ & $\begin{array}{r}-.026 \\
.808 \\
92\end{array}$ & $\begin{array}{r}-.163 \\
.120 \\
92 \\
\end{array}$ & $\begin{array}{r}-.087 \\
.411 \\
92\end{array}$ & $\begin{array}{r}1.000 \\
. \\
92\end{array}$ \\
\hline
\end{tabular}

Correlation is significant at the 0.01 level (2-tailed).

Hasil uji heteroskedastisitas pada tabel 3, dapat diketahui bahwa nilai signifikan dari variabel kualitas produk sebesar 0,126 >0,10, variabel harga sebesar 0,808 >0,10, variabel promosi sebesar $0,120>0,10$ dan variabel atribut produk sebesar 0,411 >0,10, maka dapat 
disimpulkan bahwa keempat variabel tersebut tidak terjadi problem heteroskedastisitas pada model regresi.

Tabel 4 Analisis Regresi Linier Berganda

Coefficients $^{\mathrm{a}}$

\begin{tabular}{|c|c|c|c|c|c|}
\hline \multirow[b]{2}{*}{ Model } & \multicolumn{2}{|c|}{$\begin{array}{c}\text { Unstandardized } \\
\text { Coefficients }\end{array}$} & \multirow{2}{*}{$\begin{array}{c}\begin{array}{c}\text { Standardized } \\
\text { Coefficients }\end{array} \\
\text { Beta }\end{array}$} & \multirow[b]{2}{*}{$\mathrm{t}$} & \multirow[b]{2}{*}{ Sig. } \\
\hline & B & Std. Error & & & \\
\hline 1 (Constant) & -3.765 & 4.141 & & -.909 & .366 \\
\hline Kualitas_Produk & .467 & .091 & .421 & 5.111 & .000 \\
\hline $\mathrm{Hrg}$ & .149 & .089 & .123 & 1.670 & .099 \\
\hline Promosi & .164 & .093 & .146 & 1.755 & .083 \\
\hline $\mathrm{AP}$ & .455 & .100 & .369 & 4.552 & .000 \\
\hline
\end{tabular}

Hasil uji regresi linear berganda pada tabel 4, maka persamaan regresi yang digunakan adalah:

$\mathrm{KP}=-3,765+0,467$ Kualitas produk + 0,149 Harga + 0,164 Promosi + 0,455 Atribut produk

Untuk mengetahui seberapa besar pengaruh variabel independen terhadap variabel dependennya, dapat dilihat pada tabel berikut :

\section{Tabel 5 \\ Hasil Uji Determinasi $\mathbf{R}^{2}$}

\begin{tabular}{|l|c|r|r|r|r|}
\hline Model & $\mathrm{R}$ & R Square & $\begin{array}{c}\text { Adjusted R } \\
\text { Square }\end{array}$ & $\begin{array}{c}\text { Std. Error of } \\
\text { the Estimate }\end{array}$ & Durbin-Watson \\
\hline 1 & $.727^{\mathrm{a}}$ & .529 & .507 & 1.72888 & 2.159 \\
\hline
\end{tabular}

a. Predictors: (Constant), Atribut_Produk, Harga, Kualitas_Produk, Promosi

b. Dependent Variable: Keputusan_Pembelian

Hasil koefisien determinasi pada tabel 5, dapat dilihat bahwa nilai $r=0,727$ artinya korelasi antara variabel kualitas produk, harga, promosi dan atribut produk terhadap keputusan pembelian terjadi hubungan yang kuat sebesar 0,727 . NilaiAdjusted $\mathrm{R}^{2}$ sebesar 0,507 artinyavariabel kualitas produk, harga, promosi dan atribut produk mampu menjelaskan 
PENGARUH KUALITAS PRODUK, HARGA, PROMOSI DAN ATRIBUT PRODUK TERHADAP KEPUTUSAN PEMBELIAN PASTA GIGI PEPSODENT PADA MAHASISWA JURUSAN EKONOMI SYARIAH FAKULTAS EKONOMI DAN BISNIS ISLAM IAIN PADANGSIDIMPUAN

variabel dependen atau keputusan pembelian sebesar 50,7\%. Sedangkan 49,3\% dijelaskan oleh variabel lain diluar penelitian yang dilakukan oleh peneliti.

\section{Pengaruh Kualitas Produk Terhadap Keputusan Pembelian}

Kualitas produk merupakan suatu unit sifat yang membentuk citra suatu barang atau jasa yang menentukan kemampuannya untuk memenuhi kebutuhannya.Keputusan pembelian adalah tahap dalam proses pengambilan keputusan dimana konsumen benar-benar akan membeli. Jika seseorang mempunyai pilihan antara melakukan pembelian dan tidak melakukan pembelian orang tersebut berada dalam posisi mengambil keputusan.

Secara parsialKualitas produkada pengaruh terhadap keputusan pembelian pasta gigi pepsodent dengan nilai $t_{\text {hitung }}>t_{\text {tabel }}(5.111>1,663)$.Hasil penelitin ini sejalan dengan hasil penelitian yang ditemukan Vivil Yazia yang berjudul Pengaruh Kualitas produk, Harga dan Iklan Terhadap Keputusan Pembelian menyatakan "kualitas produk berpengaruh positif terhadap keputusan pembelian”. Selain itu penelitian ini juga sejalan dengan penelitian oleh Puji Isyanto, SE., MM dan dkk yang berjudul pengaruh kualitas produk terhadap keputusan pembelian handphone blackberry pada Mahasiswa Ekonomi Universitas Siangaperbangsa Karawang menyatakan bahwa "kualitas produk berpengaruh terhadap keputusan pembelian handphone blackberry pada Mahasiswa Fakultas Ekonomi Universitas Singaperbangsa Karawang”

Jadi kesimpulannya kualitas produk berpengaruh terhadap keputusan pembelian pasta gigi pepsodent pada Mahasiswa jurusan Ekonomi Syariah Fakultas Ekonomi dan Bisnis Islam IAIN Padangsidimpuan.Untuk menjaga dan meningkatkan pembelian pasta gigi pepsodent perusahaan perlu mempertahankan kualitas dari produk itu sendiri.

\section{Pengaruh Harga Terhadap Keputusan Pembelian}


Harga merupakan sejumlah nilai (dalam mata uang) yang harus dibayar konsumen untuk membeli atau menikmati barang atau jasa yang ditawarkan.Penentuan harga merupakan salah satu aspek penting dalam kegiatan pemasaran.Penentuan harga menjadi sangat penting untuk diperhatikan mengingat harga merupakan salah satu penyebab laku tidaknya produk dan jasa yang ditawarkan.Dalam suatau hadist Rasulullah juga menganjurkan ummatnya untuk memanfaatkan mekanisme pasar dalam menyelesaikan masalah ekonomi.Islam menganjurkan agar harga diserahkan pada mekanisme pasar sesuai kekuatan permintaan dan penawaran.Pemerintah tidak boleh memihak pembeli dengan mematok harga yang lebih rendah atau memihak penjual dengan mematok harga tinggi.

Secara parsial Harga ada pengaruh terhadap keputusan pembelian pasta gigi pepsodent dengan nilai $t_{\text {hitung }}>t_{\text {tabel }}(1.670>1,663)$.Hasil penelitin ini sejalan dengan hasil penelitian yang ditemukan Nur Achidah dan dkk yang berjudul Pengaruh Promosi, Harga dan Desain Terhadap Keputusan Pembelian menyatakan "harga berpengaruh signifikan terhadap keputusan pembelian". Selain itu penelitian ini juga sejalan dengan penelitian oleh krestiawan Wibowo Santoso dkk yang berjudul pengaruh kualitas produk, harga dan promosi terhadap keputusan pembelian permen tolak angin di Semarang menyatakan bahwa " harga berpengaruh terhadap keputusan pembelian permen tolak angin di Semarang”.

Jadi kesimpulannya harga berpengaruh terhadap keputusan pembelian pasta gigi pepsodent pada Mahasiswa Jurusan Ekonomi Syariah Fakultas Ekonomi dan Bisnis Islam IAIN Padangsidimpuan.Sehingga untuk menjaga dan meningkatkan pembelian perusahaan perlu menyesuikan harga dari produk itu sendiri.

\section{Pengaruh Promosi terhadap Keputusan Pembelian}




\section{PENGARUH KUALITAS PRODUK, HARGA, PROMOSI DAN ATRIBUT PRODUK TERHADAP KEPUTUSAN PEMBELIAN PASTA GIGI PEPSODENT PADA MAHASISWA JURUSAN EKONOMI SYARIAH FAKULTAS EKONOMI DAN BISNIS ISLAM IAIN PADANGSIDIMPUAN}

Promosi adalah salah satu bagian dari bauran pemasaran yang besar peranannya.Promosi merupakan suatu ungkapan dalam arti luas tentang kegiatan-kegiatan yang secara aktif dilakukan oleh perusahaan (penjual) untuk mendorong konsumen membeli produk.Tujuan promosi adalah untuk memperkenalkan barang atau jasa agar diketahui , dibutuhkan dan diminta oleh konsumen.Aktivitas promosi juga harus sesuai dengan ketentuan syariat Islam, dimana dalam menjalankan promosi penjual harus jujur sebagaimana Imam Ghazali menulis dalam buku Ihya Ulumul "Hendaklah pedagang tidak memuji barang dagangannya dengan pujian yang sebenarnya tidak melekat padanya. Hendaklah ia tidak menyembunyikan kekurangannya dan hal-hal yang tersamar daripadanya sedikitpun.”.

Secara parsial Promosi ada berpengaruh terhadap keputusan pembelian pasta gigi pepsodent dengan nilai $t_{\text {hitung }}>t_{\text {tabel }}(1.755>1,663)$.Hasil penelitin ini sejalan dengan hasil penelitian yang ditemukan Novemy Triyandari Nugroho yang berjudul Pengaruh kualitas produk, Harga dan Promosi Terhadap Keputusan Pembelian menyatakan "promosi berpengaruh signifikan terhadap keputusan pembelian”. Selain itu penelitian ini juga sejalan dengan penelitian yang dilakukan oleh Ahmad Muanas yang berjudul pengaruh produk, harga dan promosi terhadap kepuusan pembelian mobil Buana Indomobil Trada yang mengatakan bahwa " promosi berpengaruh terhadap keputusan pembelian mobil buana indomobil trada".

Jadi kesimpulannya promosi berpengaruh terhadap keputusan pembelian pasta gigi pepsodent pada Mahasiswa Jurusan Ekonomi Syariah Fakultas Ekonomi dan Bisnis Islam IAIN Padangsidimpuan.Sehingga untuk menjaga dan meningkatkan pembelian perusahaan perlu mengembangkanpromosi untuk mengkomunikasikan informasi tentang produk yang 
diciptakan oleh perusahaan dan mempengaruhi konsumen untuk membeli dari produk itu sendiri.

\section{Pengaruh Persepsi Atribut Produk Terhadap Keputusan Pembelian}

Atribut sangat berbeda dalam hal kepentingannya bagi para konsumen.Pentingnya atribut didefinisikan sebagai penilaian umum seseorang terhadap signifikansi atribut atas produk atau jasa tertentu.Produk adalah sesuatu yang dapat ditawarkan ke pasar untuk mendapatkan perhatian untuk dibeli, digunakan atau dikonsumsi sehingga dapat memenuhi keinginan dan kebutuhan.

Secara parsialAtribut produk ada pengaruh terhadap keputusan pembelian pasta gigi pepsodent dengan nilai $t_{\text {hitung }}>t_{\text {tabel }}(4.552>1.663)$.Hasil penelitin ini sejalan dengan hasil penelitian yang ditemukan Mochammad Ikhwanuddin dkk, yang berjudul Pengaruh Atribut produk Terhadap Keputusan Pembelian yang menyatakan "atribut produk yang terdiri dari variabel merek dan kemasan berpengaruh positif atau signifikan terhadap keputusan pembelian". Selain itu penelitian ini juga sejalan dengan penelitian yang dilakukan oleh Edi Suswardji, SE., MM dkk, yang berjudul Pengaruh Atribut Produk Terhadap Keputusan Pembelian Sepeda Motor Suzuki Satria Fu (Studi Kasus Pada Dealer Suzuki Sanggar Mas Jaya Karawang) yang mengatakan bahwa " atribut produk berpengaruh terhadap keputusan pembelian sepeda motor Suzuki satria FU”.

Jadi kesimpulannya atribut produk berpengaruh terhadap keputusan pembelian pasta gigi pepsodent pada Mahasiswa Jurusan Ekonomi Syariah Fakultas Ekonomi dan Bisnis Islam IAIN Padangsidimpuan.Sehingga untuk menjaga dan meningkatkan pembelian perusahaan perlu memperhatikan atribut produk tersebut, karenaatribut produk adalah bagian yang tak bisa dipisahkan dari strategi produk yang dapat dikontrol langsung oleh perusahaan sebagai suatu rangsangan yang perlu diperhatikan oleh konsumen dalam proses keputusan pembelian. 


\section{PENGARUH KUALITAS PRODUK, HARGA, PROMOSI DAN ATRIBUT PRODUK TERHADAP KEPUTUSAN PEMBELIAN PASTA GIGI PEPSODENT PADA MAHASISWA JURUSAN EKONOMI SYARIAH FAKULTAS EKONOMI DAN BISNIS ISLAM IAIN PADANGSIDIMPUAN}

Dari atribut inilah suatu produk dipandang berbeda oleh konsumen dari produk pesaing lainnya.

\section{KESIMPULAN}

Berdasarkan pada hasil analisis data dan pembahasan mengenai pengaruh kualitas produk, harga, promosi dan atribut produk terhadap keputusan pembelianpasta gigi pepsodent pada mahasiswa Jurusan Ekonomi Syariah Fakultas Ekonomi Dan Bisnis Islam IAIN Padangsidimpuan dengan metode analisis yang digunakan yaitu regresi linier berganda, maka dapat ditarik beberapa kesimpulan sebagai berikut: pertama, Secara parsial ada pengaruh Kualitas Produk Terhadap Keputusan Pembelian pasta gigi pepsodent pada Mahasiswa Jurusan Ekonomi Syariah Fakultas Ekonomi dan Bisnis Islam IAIN Padangsidimpuan, hal tersebut dapat dibuktikan dengan melihat nilai $t_{\text {hitung }}>t_{\text {tabel }}(5,111>1,663)$ maka $\mathrm{H}_{0}$ ditolak dan $\mathrm{Ha}_{1}$ diterima. Kedua, Secara parsial ada pengaruh Harga Terhadap Keputusan Pembelian pasta gigi pepsodent pada Mahasiswa Jurusan Ekonomi Syariah Fakultas Ekonomi dan Bisnis Islam IAIN Padangsidimpuan, hal tersebut dapat dibuktikan dengan melihat nilai $\mathrm{t}_{\text {hitung }}>\mathrm{t}_{\text {tabel }}(1,670>1,663)$ maka $\mathrm{H}_{0}$ ditolak dan $\mathrm{Ha}_{1}$ diterima. Ketiga, Secara parsial ada pengaruh Promosi Terhadap Keputusan Pembelian pasta gigi pepsodent pada Mahasiswa Jurusan Ekonomi Syariah Fakultas Ekonomi dan Bisnis Islam IAIN Padangsidimpuan, hal tersebut dapat dibuktikan dengan melihat nilai $t_{\text {hitung }}>t_{\text {tabel }}(1,755>1,663)$ maka $\mathrm{H}_{0}$ ditolak dan $\mathrm{Ha}_{1}$ diterima. Keempat, Secara parsial ada pengaruh Atribut Produk Terhadap Keputusan Pembelian pasta gigi pepsodent pada Mahasiswa Jurusan Ekonomi Syariah Fakultas Ekonomi dan Bisnis Islam IAIN Padangsidimpuan, hal tersebut dapat dibuktikan dengan melihat nilai $\mathrm{t}_{\text {hitung }}>\mathrm{t}_{\text {tabel }}(4,552>1,663)$ maka $\mathrm{H}_{0}$ ditolak dan $\mathrm{Ha}_{1}$ diterima. Kelima, Secara bersamasama (simultan) ada pengaruh Kualitas Produk, Harga, Promosi dan Atribut Produk terhadap Keputusan Pembelian pastagigi pepsodent pada Mahasiswa Jurusan Ekonomi Syariah 
Fakultas Ekonomi dan Bisnis Islam IAIN Padangsidimpuan, hal tersebut dibuktikan dari $\mathrm{F}_{\text {hitung }}>\mathrm{F}_{\text {tabel }}(24,416>2,01)$, maka $\mathrm{H}_{0}$ ditolak dan $\mathrm{Ha}_{3}$ diterima.

\section{DAFTAR PUSTAKA}

Agus Sucipto, Studi Kelayakan Bisnis Analisis Integratif dan Studi Kaus, Malang: UIN-Maliki Press, 2011.

Duwi Priyatno, Pengolahan Data Terpraktis, Yogyakarta: CV. Andi Offset, 2014.

Etta Mamang Sangadji dan Sopiah, Perilaku Konsumen Pendekatan Praktis Disertai Himpunan Jurnal Penelitian, Yogyakarta: CV. Andi Offset, 2013.

Fandy Tjiptono, Strategi Pemasaran, Yogyakarta: Andi Offset, Cet 1, 1997.

Husein Umar, Metode Penelitian Untuk Skripsi dan Tesis Bisnis, Jakarta: Rajawali, 2013. , Studi Kelayakan Bisnis, Jakarta: PT. Gramedia Putaka Utama, 2005.

Leon Schiffman dan Leslie Lazar Kanuk, Perilaku Konsumen, Jakarta: PT. Indeks, 2008.

Melanie Sadono Djamil, Panduan Lengkap Kesehatan Gigi Keluarga, Solo: PT. Tiga Serangkai Pustaka Mandiri, 2003.

M. Suyanto, Marketing Strategi Top Brand Indonesia, Yogyakarta: CV. Andi Offset, 2007.

M. Fuad, dkk., Pengantar Bisnis, Jakarta: Gramedia Pustaka Utama, 2000.

Mahmud Machfoed, Pengantar Bisnis Modren, Yogyakarta: Andi, 2007.

Nasution. N. M, Manajemen Mutu Terpadu, Bogor: Penerbit Ghalia Indonesia, 2010.

Nugroho J. Setiadi, Aplikasi Teori Ekonomi dan Pengambilan keputusan Manajerial dalm Dunia Bisnis, Jakarta; Prenada Media Group, 2008

Novemy Triyandari Nugroho, “Analisis Pengaruh Kualitas Produk, Harga dan Promosi Terhadap Keputusan Pemebelian Air Mineral Kemasan”, dalam JurnalSTIMK Duta Bangsa Surakarta, Volume 8, No. 1, April 2015.

Philip Kotler dan Kevin Lane keller, Manajemen Pemasaran, Edisi Ke-12 Jilid 1, Jakarta: PT. Indeks, 2007.

Pandji Anoraga, Manajemen Bisnis, Jakarta: Rineka Cipta, 2009. 
PENGARUH KUALITAS PRODUK, HARGA, PROMOSI DAN ATRIBUT PRODUK TERHADAP KEPUTUSAN PEMBELIAN PASTA GIGI PEPSODENT PADA MAHASISWA JURUSAN EKONOMI SYARIAH FAKULTAS EKONOMI DAN BISNIS ISLAM IAIN PADANGSIDIMPUAN

Su'dan , R. H, Al-Qur'an dan Panduan Kesehatan Masyarakat, Jakarta: Dana Bhakti Prima Yasa, 1997.

Setiawan dan Dwi Endah kusrini, Ekonometrika, Yogyakarta: CV. Andi Offset, 2010.

Sugiono dan Susanto, Agus. 2015. Cara Mudah Belajar SPSS dan Lisrel Teori Dan Aplikasi Untuk Analisis Data Penelitian, Bandung : Alfabeta.

Sugiyono, Metode Penelitian Kuantitatif, Kualitatif R \& DBandung: Alvabeta, 2013.

Suryana, Kewirausahaan, Jakarta: Salemba Empat, 2013.

Ujang Sumarwan, Perilaku Konsumen Teori dan Penerapannya dalam Pemasaran, Cet 1, Edisi 2, Bogor: Penerbit Ghalia Indonesia, 2011. 